\title{
THE HISTORY AND CURRENT STATUS OF OPTOMETRIC EDUCATION IN AFRICA
}

\author{
Sampson Listowell Abu, OD \\ Department of Ophthalmology \\ and Visual Sciences University of \\ Alabama at Birmingham \\ Birmingham, Alabama 35233 \\ sabu@uabmc.edu
}

10.14434/hindsight.v51i4.31557

\begin{abstract}
Over the past decade, 16 new optometry programs have been established across Africa and there are efforts to set up additional training institutions in the future. Also, existing optometry programs are undergoing modifications to offer an international standard of optometric education and training. This paper focuses on the history and further assesses the current status of optometric education on the continent of Africa. Additionally, optometric education in Africa is compared to North American training programs. Challenges facing optometric programs in Africa are highlighted with recommendations to address them.
\end{abstract}

\section{KEYWORDS}

International optometry, optometric education, optometry school curricula, optometry degrees, optometry history.

\section{INTRODUCTION}

It is believed that the noble beginnings of optometry are tied closely to the invention of spectacles in the early 1300s. ${ }^{1,2}$ Optometry has evolved from the art of making eyeglasses into a sophisticated health care profession. The World Council of Optometry (WCO) proffers the most contemporary definition of optometry- "a healthcare profession that is autonomous, educated, and regulated (licensed/registered), and optometrists are the primary healthcare practitioners of the eye and visual system who provide comprehensive eye and vision care, which includes refraction and dispensing, detection/diagnosis and management of disease in the eye, and the rehabilitation of conditions of the visual system".3

Even though formal optometric education and training began over 130 years ago, 2,4 the level of education and scope of practice varies around the globe., 5, 6 In Africa, the first optometry training institution was established in South Africa in 1924. By 1993, three more countries, Ghana, Nigeria, and Tanzania, had optometry training programs. ${ }^{7}$ A recent report by the International Agency for the Prevention of Blindness-Africa identified 27 optometry training institutions in 15 Sub-Saharan African countries. ${ }^{8}$ The growing number of optometry programs stems partly from a regional campaign ${ }^{9}$ to provide more human resources for eye health in Sub-Saharan Africa. This effort aligns with the core strategies to achieve the targets of VISION 2020: a global initiative to eliminate avoidable blindness. ${ }^{10}$
As new schools emerge on the continent, it is imperative to keep an updated historic account of the development of optometric education in Africa. A record of the history juxtaposed to the current status of optometry education will give cause for reflection on the strides that have been made in expanding optometric education in Africa. Highlighting the obstacles that confronted the establishment of existing programs offers guidance to emerging optometry institutions. Furthermore, such an account can serve as a reference in the teaching of the distinguished heritage of optometric education in Africa and further help students obtain a better understanding of the roots of their chosen profession. The purpose of this paper is to provide a concise historical account of optometric education on the continent. This paper also describes the current status of optometric education in Africa and how it compares to optometric training in North America.

Information provided in this paper resulted from interviews of resource persons and a review of the existing literature. Resource persons consisted of current deans of optometry programs, individuals involved setting up optometry programs in Africa and foreign nationals who teach or have taught in African optometry schools. Interviews were conducted through video calls, telephone conversations and, in some cases, written responses to questions of interest. In all cases, published and unpublished documents relating to the subject matter were obtained from verifiable sources.

\section{HISTORY OF OPTOMETRIC EDUCATION IN AFRICA}

The continent of Africa has 55 recognized states grouped geographically into five subregions: Northern Africa, Central 
Africa, Eastern Africa, Western Africa, and Southern Africa. These subregions are frequently used by the United Nations Statistics Division for statistical purposes. The history of optometric education in each subregion is described below. Due to the different levels of optometric education offered across Africa, ${ }^{6}$ only training programs consistent with WCO competency categories 2 to 4 are considered in this section. ${ }^{3}$ The categories 2 to 4 describes a set of competencies that expands from the provision of visual function services and ocular diagnostic and therapeutic services. In the WCO competency module, practitioners at level 2 and upwards are considered as optometrists. ${ }^{3}$

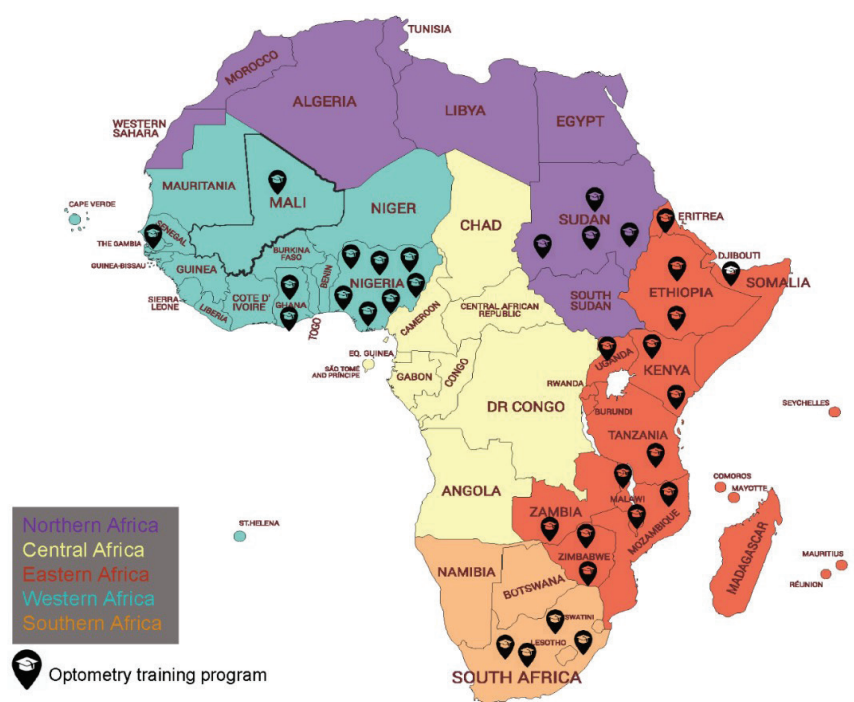

A map of Africa showing the subregional distribution of optometry programs.

\section{Northern Africa}

With a population of approximately 244 million, Northern Africa has four recognized optometry training institutions, all situated in Sudan.

\section{Sudan}

Optometric education in Sudan started in 1954 with the establishment of the School of Refractionists. ${ }^{6}$ The program was initially intended to train assistants for ophthalmologists at the Khartoum Eye Hospital. The program evolved into the Institute of Optometry, which modified the refraction training course into a Diploma in Optometry program. In 1977, the Institute of Optometry merged with Al-Neelain University and was renamed the Faculty of Optometry and Visual Sciences. Following the merger, Al-Neelain University instituted a five-year Bachelor of Science in Optometry program. In 2002, the Faculty of Optometry and Visual Sciences rolled out graduate optometry degree programs (master's and PhD). Since then, three additional institutions (one public and two private) have started the five-year Bachelor of Science in Optometry program. Ibn Sina
University and Makka College of Optometry started their optometry training programs in 2016, whereas University of West Kordofan, another public university, commenced their program in 2017.

\section{Central Africa}

Currently, there is no optometry training program in this region. The Brien Holden Vision Institute (BHVI) previously surveyed the feasibility of starting an optometry program in Cameroon to serve the French-speaking Africa countries. ${ }^{11}$ In recent efforts, the Cameroon Optometry Association has reached an agreement with the University of Buea to commence optometry education in 2020. The School, located in Southwestern Cameroon, will offer a six-year Doctor of Optometry (OD) degree program. Currently offered in Ghana and Nigeria, the six-year program is the highest level of optometry education in Africa and it includes pre-optometry basic science courses and optometry curriculum.

\section{Eastern Africa}

There are 14 optometry training institutions in 10 of the 19 Eastern African Countries: Ethiopia, Eritrea, Kenya, Malawi, Mozambique, Somaliland, Tanzania, Uganda, Zambia, and Zimbabwe.

\section{Ethiopia}

Ethiopia has two institutions offering the Bachelor of Optometry degree program. The first program was set up in 2005 at the University of Gondar in Gondar, north of Addis Ababa, Ethiopia's capital city. ${ }^{12}$ The Department of Optometry, which is administratively under the Faculty of Health Sciences, also offers a Master's in Optometry degree. The optometry program at the University of Gondar came into being through the joint efforts of Mrs. Gemma Peters, a UK-trained optometrist, and ORBIS International, a non-profit organization committed to saving sight around the globe. In 2008, another four-year Bachelor of Optometry degree was started by the College of Medicine and Health Sciences of Hawassa University, which is approximately 280 kilometers south of Addis Ababa.

\section{Eritrea}

The only optometric training program in Eritrea is offered by the Asmara College of Health Sciences, in the city of Asmara. BHVI, in partnership with the Eritrean Ministry of Health and Asmara College of Health Sciences, initially developed a two-year diploma program in 2009.8,13 The program started training optometric technicians in 2010 as a short term and immediate solution to the dire need for refractive services in Eritrea. A 5-year Bachelor of Science in Optometry was implemented in 2013 to replace the 
diploma program, which was phased out in 2016. The first cohort of students who were enrolled in the bachelors' program graduated in August 2019.

\section{Kenya}

A three-year diploma course and a four-year Bachelor of Science in Optometry program are offered at the Kenya Medical Training College (KMTC) and Masinde Muliro University of Science and Technology (MMUST), respectively. The diploma program was introduced in 2006 under the Department of Occupational Therapy of KMTC, located in Nairobi. The program stood on its own as the Department of Optometry in 2011. With continued efforts to train more doctors, BHVI collaborated with the Kenyan government to establish in 2009 the four-year program at MMUST, located at Kakamega. ${ }^{5}$ The Department of Optometry and Vision Sciences oversees the four-year Bachelor of Science in Optometry program. The department additionally offers a master's degree program in optometry.

\section{Malawi}

Malawi has two optometry training programs. Established in 2008, the School of Optometry at the Mzuzu University in Mzuzu started to train the country's first group of optometrists in 2009. ${ }^{6}$ The school runs a five-year Bachelor of Optometry program. The program was established through partnership between BHVI, the Malawi Department of Health and Mzuzu University. Two other nonprofit organizations, Optometry Giving Sight and Sightsavers, provided funds to support the establishment of Mzuzu University School of Optometry. The Malawi Colleges of Health Sciences, located in Lilongwe, commenced a three-year diploma course in 2010.,14 This program trains optometric technicians to assist optometrists and ophthalmologists in the country.

\section{Mozambique}

The University of Lúrio in Nampula, a public university located in northern Mozambique, offers a four-year Bachelor of Science in Optometry. ${ }^{6,15}$ The University of Lúrio is the first and only institution that offers optometry training in Mozambique and in the entire Lusophone Africa. The optometry training program was established in 2008 through the Mozambique Eyecare Project with support from the Irish Aid and the BHVI. ${ }^{16}$ The Dublin Institute of Technology and the University of Ulster provided additional support.

\section{Tanzania}

The optometry school at the Kilimanjaro Christian Medical University College in Moshi is the oldest training program in Eastern Africa. A joint effort by the Tanzanian Ministry of Health, Swedish Federation of the Visually handicapped
(SRF) and the Eye Department of the Kilimanjaro Christian Medical Center (KCMC) led to the establishment of a threeyear diploma course in optometry. The SRF was instrumental in the development of the program's curriculum. The program is taught within the optometric facilities of the KCMC Eye Department. In 1985, the government of Tanzania assumed sole ownership of the training program. The program has increased its initial enrollment capacity of 10 students per year to 30 students per year, which include students from neighboring countries. Since 2005, there have been efforts to transition the program into a four-year Bachelor of Science in Optometry degree program that would train students to a globally-recognized higher level of competency and to create an opportunity for the Diploma in Optometry holders to upgrade their knowledge and skills. It is believed the four-year program, which kicked off in 2019, will eventually replace the diploma program.

\section{Uganda}

Efforts to establish an optometry training program in Uganda started in 2004 with Dr. Naomi Nsubuga, the Sub-regional manager for the BHVI, playing an active role. In 2013, the Makerere University in Kampala opened its doors to the establishment of the country's first optometry training program. ${ }^{16}$ The College of Health Sciences, in partnership with the BHVI, developed a four-year Bachelor of Optometry training program. The BHVI provided training equipment, curriculum development and teaching staff to ensure the program's smooth inception. Other organizations that contributed immensely to the development of the program include the Australian Department of Foreign Affairs and Trade, the University of New South Wales in Australia, Optometry Giving Sight, Light for the World and the Optometrist Association of Uganda. 16,17 The first cohort of trainees consisted of five individuals who graduated in January 2019 and became the school's first optometrists.

\section{Zambia}

Zambia's first optometry program was established in 2010 through a partnership between Vision Aid Overseas and the Chainama College of Health Sciences in Lusaka. The college offers a three-year diploma program that trains optometric technicians. ${ }^{6}$ While the program was developed and supported by Vision Aid Overseas, it received additional funding from Specsavers. In 2018, the Chainama College of Health Sciences merged with the Dental Training School, Levy Mwanawasa University Teaching Hospital and the Chainama Hills Hospital to form the Levy Mwanawasa Medical University (LMMU). After its establishment as a public university, LMMU introduced a four-year Bachelor of Science in Optometry program in addition to the three-year optometric technician diploma program. These optometry programs are administered by the LMMU School of Medicine and Clinical Sciences. 


\section{Zimbabwe}

The latest African country to train optometrists locally is Zimbabwe. Two training programs were established in 2018 at the University of Zimbabwe and the Bindura University of Science Education. Both institutions offer the four-year Bachelor of Optometry degree program. The Cimas Medical Aid Society supported the optometry program at the University of Zimbabwe by providing training instruments and furnishing the optometry training units within the Kaguvi Hospital in Harare. The Bindura University optometry program, which commenced late in 2018, was supported by the Premier Service Medical Investments. Dr. Finn Juncker, an optometrist from Denmark, also facilitated the donation of training equipment to the program.

\section{Somaliland}

The University of Hargeisa in Hargeisa established a fouryear Bachelor of Optometry program in 2014. Its first class of students graduated in 2018. Available information from the school's website indicates a temporary suspension of the program. ${ }^{18}$

\section{Western Africa}

Four out of the 17 West African countries have institutions that offer optometric education.

\section{Ghana}

There are two public universities that offer optometric education in Ghana: the Kwame Nkrumah University of Science and Technology (KNUST) and the University of Cape Coast (UCC). Each institution offers a six-year optometry degree program. ${ }^{6}$ Optometric education in Ghana was necessitated by the need to increase the number of optometrists for legal recognition and registration of optometry as a profession in the country. Following earlier unsuccessful attempts to get public universities to set up an optometry training program, the late Dr. Francis K. Morny (a British-trained Ghanaian optometrist) established the Premier College of Optometry in 1998. 19, 20

Prior to the establishment of Premier College of Optometry, optometric training in Ghana existed only in the form of an apprenticeship. The college retrained and awarded ophthalmic optician certificates to practicing refracting opticians who had no formal training. In 1990, the college offered a one-year postgraduate diploma in optometry. This program was later accepted by the University of Science and Technology (now KNUST) and expanded into a two-year course offered under the Department of Physics. ${ }^{19}$ The program only admitted students who had already obtained their bachelor's degrees in any of the basic sciences. In 2000, KNUST adopted a four-year Bachelor of Science in Optometry curriculum despite an initial proposal for a six-year optometry program. Not relenting on his ambition, Dr. Morny approached the University of Cape Coast with a six-year optometry degree program proposal. The University of Cape Coast welcomed the idea and established the first OD program in 2002. Subsequently, the Department of Optometry at KNUST abandoned its four-year program and adopted the six-year model in 2004..$^{20}$ Both institutions have since expanded and are laying the groundwork to offer postgraduate degrees in optometry and vision science.

\section{Nigeria}

Records indicate that Nigeria was the first country to have both the Bachelor and Doctor of Optometry degree programs in Africa. ${ }^{6,7}$ Currently, seven institutions offer a sixyear optometry degree program. Optometric education in Nigeria began in 1970 with a four-year Bachelor of Science in optometry degree offered by the University of Benin in Benin City. This four-year program was revised in 1994 to be consistent with the optometry degree programs that had been introduced by Abia State University and Imo State University in 1980 and 1993, respectively.2. A Master of Science and a PhD in optometry also are offered at the University of Benin. In the past two decades, four more universities have established optometry degree programs in Nigeria. Madona University, a private institution, began to offer optometric education in 2006. The Federal University of Technology in Owerri changed its bachelor's degree in optical technology to the optometry degree in 2010. University of Ilorin and Bayero University established their optometry programs in 2013 and 2015, respectively.

\section{Mali}

The School of Optometry at the African Institute of Tropical Ophthalmology in Bamako was established in 2009. 6,8 The school trains optometric technicians in a threeyear diploma program. It is the first and only optometric education program offered in Francophone Africa. The program has been supported by the International Centre for Eyecare Education (BHVI). The first cohort of trainees graduated in 2011. The program has benefited from visiting lecturers from the School of Optometry at the University of Montreal, Canada.

\section{The Gambia}

In 2001, the Regional Ophthalmic Training Program (ROTP) was established in The Gambia to offer different ophthalmic training programs, which included a one-year optometric technician diploma course. The ROTP is currently based at the Sheikh Zayed Regional Eye Care Centre in Kanifing, which was commissioned in 2007. It was built with funds provided by Sightsavers and Zayed Bin Sultan Al Nahayan, a nonprofit organization based in the United Arab Emirates. 


\begin{tabular}{|c|c|c|c|c|c|c|c|c|}
\hline Subregion & Country & $\begin{array}{c}\text { Number of } \\
\text { Schools }\end{array}$ & Name of Institution & $\begin{array}{l}\text { Year } \\
\text { established }\end{array}$ & $\begin{array}{l}\text { Level of Optometric } \\
\text { education }\end{array}$ & $\begin{array}{l}\text { Duration of } \\
\text { training (years) }\end{array}$ & $\begin{array}{l}\text { Graduate } \\
\text { programs }\end{array}$ & Location \\
\hline \multirow{4}{*}{$\begin{array}{l}\text { Northern } \\
\text { Africa }\end{array}$} & \multirow{4}{*}{ Sudan } & \multirow[t]{4}{*}{ ( } & AI Neelain University & 1997 & Bachelor of Optometry & 5 & Master's, PhD & Khartoum \\
\hline & & & Ibn Sina University & 2016 & Bachelor of Optometry & 5 & - & Khartoum \\
\hline & & & Makka college of optometry & 2016 & Bachelor of Optometry & 5 & - & Khartoum \\
\hline & & & University of West Kordofan & 2017 & Bachelor of Optometry & 5 & - & El-Nuhud \\
\hline \multirow{14}{*}{$\begin{array}{l}\text { Eastern } \\
\text { Africa }\end{array}$} & Tanzania & 1 & $\begin{array}{l}\text { Kilimanjaro Christian Medical University } \\
\text { College }\end{array}$ & 1979 & $\begin{array}{l}\text { Diploma in Optometry } \\
\text { Bachelor of Optometry }\end{array}$ & $\begin{array}{l}3 \\
4\end{array}$ & & Moshi \\
\hline & \multirow[t]{2}{*}{ Ethiopia } & \multirow[t]{2}{*}{2} & University of Gondar & 2005 & Bachelor of Optometry & 4 & Master's & Gondar \\
\hline & & & Hawassa University & 2008 & Bachelor of Optometry & 4 & - & Hawassa \\
\hline & \multirow[b]{2}{*}{ Kenya } & \multirow[b]{2}{*}{2} & Kenya Medical Training College & 2006 & Diploma in Optometry & 3 & & Nairobi \\
\hline & & & $\begin{array}{l}\text { Masinde Muliro University of Science and } \\
\text { Technology }\end{array}$ & 2009 & Bachelor of Optometry & 4 & Master's & Kakamega \\
\hline & \multirow[b]{2}{*}{ Malawi } & \multirow[b]{2}{*}{2} & \multirow{2}{*}{$\begin{array}{l}\text { Mzuzu University } \\
\text { Malawi College of Health Sciences }\end{array}$} & 2008 & Bachelor of Optometry & 5 & - & Mzuzu \\
\hline & & & & 2009 & Diploma in Optometry & 3 & - & Lilongwe \\
\hline & Mozambique & 1 & Lúrio University & 2009 & Bachelor of Optometry & 4 & - & Nampula \\
\hline & Eritrea & 1 & Asmara College of Health Sciences & 2009 & Bachelor of Optometry & 5 & - & Asmara \\
\hline & Zambia & 1 & $\begin{array}{l}\text { Chainama college of health sciences } \\
\text { (now Levy Mwanawasa Medical University) }\end{array}$ & 2010 & $\begin{array}{l}\text { Diploma in Optometry } \\
\text { Bachelor in Optometry }\end{array}$ & $\begin{array}{l}3 \\
4\end{array}$ & - & Lusaka \\
\hline & Uganda & 1 & Makerere University & 2013 & Bachelor of Optometry & 4 & - & Kampala \\
\hline & & & University of Zimbabwe & 2018 & Bachelor of Optometry & 4 & - & Harare \\
\hline & Zimbabwe & 2 & Bindura University of Science Education & 2018 & Bachelor of Optometry & 4 & - & Bindura \\
\hline & "Somaliland & 1 & University of Hargeisa & 2014 & Bachelor of Optometry & 4 & - & Hargeisa \\
\hline \multirow{11}{*}{$\begin{array}{l}\text { Western } \\
\text { Africa }\end{array}$} & \multirow{7}{*}{ Nigeria } & \multirow{7}{*}{7} & University of Benin & 1970 & Doctor of Optometry & 6 & Master's, PhD & Benin city \\
\hline & & & Abia State University & 1980 & Doctor of Optometry & 6 & - & Uturu \\
\hline & & & Imo State University & 1993 & Doctor of Optometry & 6 & - & Owerri \\
\hline & & & Madona University & 2004 & Doctor of Optometry & 6 & - & Okija \\
\hline & & & Federal University of Technology & 2010 & Doctor of Optometry & 6 & - & Owerri \\
\hline & & & University of llorin & 2013 & Doctor of Optometry & 6 & - & Ilorin \\
\hline & & & Bayero University & 2015 & Doctor of Optometry & 6 & - & Kano \\
\hline & \multirow[t]{2}{*}{ Ghana } & \multirow[t]{2}{*}{2} & $\begin{array}{l}\text { Kwame Nkrumah University of Science and } \\
\text { Technology }\end{array}$ & 1991 & Doctor of Optometry & 6 & Master's, PhD & Kumasi \\
\hline & & & University of Cape Coast & 2002 & Doctor of Optometry & 6 & - & Cape Coast \\
\hline & The Gambia & 1 & Sheikh Zayed Regional Eye Care Centre & 2006 & Diploma in Optometry & 1 & - & Kanifing \\
\hline & Mali & 1 & African Institute of Tropical Ophthalmology & 2009 & Diploma in Optometry & & - & Bamako \\
\hline \multirow{4}{*}{$\begin{array}{l}\text { Southern } \\
\text { Africa }\end{array}$} & \multirow{4}{*}{ South Africa } & \multirow{4}{*}{4} & University of Limpopo & 1975 & Bachelor of Optometry & 4 & Master's & Turfloop \\
\hline & & & University of KwaZulu-Natal & 1979 & Bachelor of Optometry & 4 & Master's, PhD & Durban \\
\hline & & & University of Johannesburg & 1985 & Bachelor of Optometry & 4 & Master's, DPhil & Johannesburg \\
\hline & & & University of Free State & 2002 & Bachelor of Optometry & 4 & Master's & Bloemfontein \\
\hline
\end{tabular}

Name, number, year of establishment and location of optometry schools within each subregion

Since its inception, the ROTP has welcomed and trained students from other African countries without optometry programs. During the Centre's 10-year anniversary in 2017, it was reported that the Regional Ophthalmic Training Program had trained over 400 eyecare professionals from 20 Sub-Saharan African countries.

\section{Southern Africa}

Five states make up Southern Africa; however, optometric education in this subregion is currently offered by four institutions, all based in South Africa.

\section{South Africa}

Historically, formal optometric education on the continent of Africa began in South Africa with the establishment of a diploma program in 1924 at the Technikon Witwatersrand in Johannesburg. This initial two-year, part-time course underwent a series of transitions. By 1969, it was offered as a four-year, full-time diploma program.6,22 The Rand Afrikaans University also started a four-year Bachelor of Optometry program in 1985. Due to the apartheid system then, these two programs enrolled only white South African students. The two universities merged in 2004 to become the University of Johannesburg, which continues to offer the four-year Bachelor of Optometry degree. Prior to this, the first four-year Bachelor of Optometry program had been established in 1975 at the University of the North in Turfloop..$^{23}$ The program provided optometric training for black South Africans. The University of the North and the Medical University of South Africa merged in 2005 and became the University of Limpopo. Four years after the establishment of the University of the North optometry program, a similar training program was started by the University of Durban-Westville in Durban. ${ }^{22}$ This program was set up to offer optometric education to the Indian population who had largely settled in and around the Durban area during apartheid. After its merger with the University of Natal in 2004, the University of DurbanWestville was renamed the University of KwaZulu-Natal and continues to offer optometric education at the Durban campus. Post-apartheid, the University of Free State in Bloemfontein commenced a four-year Bachelor of Optometry program in 2002. All the four universities also offer postgraduate education in optometry.

\section{THE STATE OF OPTOMETRIC EDUCATION IN AFRICA}

Thirty-three institutions in 16 countries provide optometric education to approximately 1.2 billion people 
living in Africa. While there are optometry programs in most regions of Africa, with the majority being found in Eastern Africa, there is yet to be an optometric institution established in Central Africa. Most of the optometry programs are taught in English, though Africa is linguistically diverse. Currently, only the University of Lúrio in Mozambique offer optometric education in Portuguese. There is a two-year training program in Cote D'Ivoire that teaches opticians how to perform refraction; ${ }^{6}$, however, the African Institute of Tropical Ophthalmology in Mali offers most advanced optometric education in Francophone Africa.

\section{Level of Optometric Education and Training}

The fundamental objective for optometry programs in Africa is to train competent optometrists to provide primary eye care. ${ }^{8}$ The curricula of the programs reflect a strong emphasis on refractive error correction and the detection and management of ocular abnormalities. Notwithstanding, training programs that span over 4 to 6 years expose students to advanced or specialty areas in optometry, such as binocular vision, contact lenses and low vision rehabilitation. Moreover, optometric education is not standardized across Africa. ${ }^{6}$ Over the years, training institutions, governmental agencies and other stakeholders have determined the duration of education and curriculum deemed satisfactory to train optometrists in a given country. This has contributed to the existence of different levels of optometric education on the continent. While the sixyear optometry degree program offered by the Ghanaian and Nigerian institutions remain the highest level of optometric education in Africa, optometric institutions in other countries are phasing out the diploma -level training and adopting the four- or five-year Bachelor of Optometry degree program.

The lack of standardized education and clinical training implies different licensure requirements and scope of practice across the continent. In view of this, the African Council of Optometry is championing efforts to address the non-existence of an initiative or policy to standardize optometric education on the continent. Past attempts to upgrade the level of optometric education in countries with lower levels of education and training have been met with internal and external resistances. ${ }^{18}$ Certain political actors and professional bodies with competing interests in eye care cause deliberate impediments and undue complications to frustrate initiatives that advance optometric education. Additionally, the fiscal implications that come with higher levels of training, such as higher salary demands, discourage the advancement of policies supporting higher optometric education and expanded scope of practice.

\section{Staff Strength}

A common challenge facing all the optometry programs in Africa is insufficient teaching and clinical staff. 6 The few available educators are overburdened by heavy course loads, large class sizes and, in some instances, teaching courses outside their scope of expertise. Due to insufficient clinical staff (preceptors), the teaching staff may take on additional clinic supervisory duties. To boost staff strength, most programs retain some of their graduates and mobilize support in terms of scholarships for them to pursue higher academic degrees. For example, three of the first optometrists who graduated from the University of Cape Coast in 2008 were retained and have subsequently obtained their PhD degrees. They now teach in the program. Similar initiatives are being pursued by optometric institutions in Kenya, Mali, Mozambique, and Uganda. Through international partnerships, some faculty members of foreign optometry institutions have taught in Africa as visiting lecturers. The optometry program at the University of Gondar in Ethiopia is one of the many institutions that have benefited from such an initiative.

\section{Training Resources}

As expected, the training institutions have labs and clinic facilities for the practical aspect of optometric education. However, these facilities are not well equipped with the state of art instruments. In other cases, the available teaching and learning resources may be inadequate, thereby presenting a challenge for practical demonstrations by educators and for hands-on practice by students. Again, the limited resources break down frequently due to overuse by students who may not have the funds to purchase personal, basic training equipment. The situation is likely to worsen, given the recent higher records of enrollment and adoption of an advanced level of optometric education.

\section{Externship and Internship}

Externship and internship programs have been valuable resorts to augment the students' clinical knowledge and experience, considering the insufficient staff and limited training resources. Some training institutions structure externship programs around vacation periods and require students to spend an approved minimum number of hours at recognized eye care facilities. In some countries, internship programs are regulated and done after graduation. For instance, in Ghana, Nigeria and Sudan, new optometry graduates must undergo a yearlong internship before being permitted to sit for the state licensure exam. The internship period involves working under the supervision of an experienced optometrist in both primary care and specialty clinics. This supervised training program enhances the confidence and competence of new graduates and further exposes them to a diverse scope of optometric practice. 


\section{Sources of Support}

Most optometry programs in Africa are offered by public universities and, therefore, rely on government support that is infrequent or often delayed. Optometry institutions in Africa rely heavily on partnerships with local and foreign non-profit organizations, as well as private entities. There also are optometry schools that were established through collaborations between governments and nonprofit organizations. For example, BHVI has been involved in such collaborations in six or more African countries and elsewhere in the world. ${ }^{11}$ The agency's involvement in the expansion of optometric education in different parts of the world includes need assessment, advocacy, resource mobilization, implementation and development of optometry curricula. Optometry Giving Sight, Optical Foundation, Sightsavers, Volunteer Optometric Services to Humanity, Cimas Medical Aid Society and Vision Aid Overseas add to the long list of agencies that have contributed to the development of optometry in Africa.

\section{COMPARISON OF OPTOMETRIC EDUCATION BETWEEN AFRICA AND NORTH AMERICA}

Currently, there are 25 optometric institutions across North America, which includes the University of Waterloo and the University of Montreal in Canada. Each of these institutions offer a four-year optometry program. Optometric education continues to expand across Africa, while existing programs aspire to meet international standards of education and training. It is therefore of essence to highlight the similarities and differences that exist between optometric education in Africa and that offered in North America, which is considered the most advanced level of optometric education in the world. ${ }^{3}$

\section{Similarities}

The evolution of optometric education in Africa is comparable to the development of formal optometry training in North America. In both continents, apprenticeship in opticianry were offered by optical shop owners who were refracting opticians trained in England., 2, 16,22 Subsequently, well-structured training programs offered by academic institutions went through several modifications in terms of duration and curriculum. The current six-year Doctor of Optometry program offered in Ghana and Nigeria is synonymous to an earlier form of optometric education in the United States. ${ }^{6} 20$ In the 1960s, all optometry schools operated a two-year, pre-optometry plus a four-year intensive optometry curriculum. ${ }^{2}$ Remnants of that system are seen in North American optometry programs that require at least three years of college education followed by the four-year Doctor of Optometry training.

Apart from the historical resemblance, similar foundational courses are taught in optometry programs offered in both
Africa and North America. Geometric and physical optics, visual optics, ophthalmic lens and materials, ocular anatomy and physiology and ocular biochemistry are just a few of the preclinical courses that can be found in optometry curricula on both continents. Another similarity is that graduates from optometric programs in both Africa and North America are required to take board-regulated examinations in order to obtain licensure to practice. These exams are, however, structured differently in both continents. To the best of the author's knowledge, Ghana, Nigeria and Sudan are the only African countries that have board-regulated licensure exams.

\section{Differences}

Optometric education is standardized in North America, as the Doctor of Optometry degree is the only recognized level of education and training for licensure to practice. ${ }^{4}$ In contrast, different levels of optometric education are recognized in Africa. Diploma, Bachelor and Doctor of Optometry degrees are awarded across the continent. ${ }^{6}$ The minimum level of optometric education recognized in a particular African country is partly determined by its eye care needs and capacity to train optometrists. ${ }^{8}$ Unlike the standard four-year duration in North America, optometric education in Africa can take two, four, or 6 years to complete. The differences in the level and years of training make it challenging to institute standardized competency board exams across Africa.

The minimum entry requirements for admission into optometry programs differ between Africa and North America. In North America, three to four years of undergraduate education is required for acceptance into a Doctor of Optometry program. ${ }^{2,4}$ Optometry institutions in Africa require at least completion of secondary (high) school education ${ }^{15,20}$ or its equivalent and usually admit students with strong backgrounds in mathematics, biology, chemistry and physics. In contrast to the optometry school admission process in Africa, Northern American institutions require applicants to take standardized admission tests, such as the Optometry Admissions Test.

Moreover, postgraduate clinical education in the form of residency and fellowship programs are non-existent in Africa. North American optometry programs offer wellstructured and coordinated residency training in more than 10 specialty areas. The Association of Schools and Colleges of Optometry recently reported a total of 475 residency slots affiliated with optometry schools in the United States and Canada. ${ }^{24}$ Residency training, which mostly lasts for a year, further deepens clinical knowledge and expertise in areas such as primary care, pediatric optometry, ocular disease, cornea and contact lenses and low vision rehabilitation, among others. The African Council of Optometry has outlined guidelines for regional optometry institutions to obtain accreditation to offer advanced training in low vision 
rehabilitation..$^{25}$ It is hoped that this would be the first step towards the development of optometry residency programs relevant to eye care needs in Africa.

\section{RECOMMENDATIONS}

An appraisal of the current status of optometric education in Africa reveals that training institutions and programs face similar challenges. The most common challenges are insufficient teaching staff and limited training equipment. These challenges having been highlighted in earlier reports persist. 6,7 Graduate retention has been a major conduit to increase staff strength and must be strengthened. Optometry institutions in Africa should also establish new state-of-the-art relationships and deepen existing partnerships with foreign optometry schools in the interest of pursuing an active visiting professor program. Alternatively, training institutions can leverage recent technological advancements to develop online teaching platforms. These platforms can be used to facilitate remote teaching and learning, whereby experts or foreign professors may be invited to speak on certain topics or teach courses for which expertise is lacking in African schools. Depending on the nature of relationships with foreign optometry schools, students in Africa can use electronic media to access live classes or recorded lectures.

State of the art training equipment for effective optometric education and training also is lacking in most programs. Since almost all optometry institutions in Africa are state owned, appropriate government ministries are expected to provide the needed financial support to procure teaching and learning resources. Apart from donations from non-governmental organizations, optometry institutions should identify additional means of raising funds to support the program. For instance, funds generated internally from campus and satellite training clinics can be put towards the cause of purchasing new equipment.

The implementation of the African Continental Free Trade agreement calls for renewed interest in standardizing optometric education across the continent. The African Council of Optometry and other stakeholders must solidify efforts and develop roadmaps to ensure that optometric education is harmonized across Africa. In this vein, similar efforts must be directed to developing much needed postgraduate clinical programs focusing on primary care, low-vision rehabilitation and community health optometry. The pursuit of standardized optometric education and residency programs will go a long way to expanding the scope of optometric practice in Africa and elevating its quality to rival that of other parts of the world.

\section{CONCLUSION}

Formal optometric education in Africa began nearly a century ago. There has been a remarkable increase in the number of optometry institutions over the past decade with the establishment of 16 new training programs. This trend is expected to continue as the entire continent increasingly becomes aware of the optometry profession and the immense need it serves. As new programs emerge, existing institutions must upgrade the level of optometric education and training to emulate the higher global standards of the profession. There are significant and similar challenges facing all optometric institutions on the continent. Solutions to these problems demand a multifaceted approach involving all key players: governments, national optometric associations, domestic and foreign nonprofit organizations and private entities.

\section{ACKNOWLEDGEMENTS}

This work was supported by the David and Diane Goss Optometry History Fellowship through the American Academy of Optometry Foundation. The author thanks Dr. Lyne Racette, University of Alabama, Birmingham, for her support during the fellowship period. The author also is grateful to the following individuals who spared valuable time to share useful information on optometric education in Africa.

Luigi Bilotto, OD; Former Director of Global Education, BHVI Kesi Naidoo, Global Resource Centre Manager, BHVI-Africa

Khathutshelo Percy Mashige, PhD; Department of Optometry, University of KwaZulu-Natal

Bharat Kumar Bhayal; Former Lecturer, Asmara College of Health Sciences, Eritrea

Daniel Achugwo, OD; Lecturer, Department of Optometry Asmara College of Health Sciences

Lynett Masiwa; Lecturer, Department of Optometry, University of Zimbabwe

Mauricio Pene; BHVI- Mozambique

Diane van Staden; Head of Optometry Department, University of KwaZulu-Natal

Dr Thokozile Ingrid Metsing; Head of Optometry

Department, University of Johannesburg

Jeffrey Walline, OD, PhD; Associate Dean for Research, The Ohio State University College of Optometry

Douglas Horner OD, PhD; Professor Emeritus, Indiana University School of Optometry

Ayukotang Enowntai Nkongho, OD; Secretary for AFCO and Cameroon Optometry Association

Husseinali Datoo; Optometrist, Vision Plus Eye Clinic, Tanzania 
Saif Alrasheed, PhD; Former Lecturer, Faculty of Optometry and Vison Sciences, Al-Neelain University

Atif B M Ali Osman, PhD; Lecturer, Faculty of Optometry and Vison Sciences, Al-Neelain University

Samuel Kyei, OD, PhD; Department of Optometry, University of Cape Coast, Ghana

\section{REFERENCES}

1. Rosen E. The invention of eyeglasses. J Hist Med Allied Sci 1956;11:13-46,183-218

2. Goss DA. Landmarks in the history of optometry. Hindsight. 2007;38(2):47-54.

3. World Council of Optometry. A global competencybased model of scope of practice in optometry. 2015. Retrieved from https://worldcouncilofoptometry. info/wp-content/uploads/2017/03/wco_global_ competency_model_2015.pdf

4. Register SJ. A backward glance on optometric education: institutional profile of schools and colleges of optometry. Optometric Education. 2011;36(2):76-81.

5. Padilla MA, Di Stefano AF. A snapshot of optometry around the world. Rev Optom 2009;15:55-7. Retrieved from https://www.reviewofoptometry.com/article/asnapshot-of-optometry-around-the-world

6. Oduntan OA, Mashige KP, Kio FE, Boadi-Kusi SB. Optometric education in Africa: historical perspectives and challenges. Optom Vis Sci. 2014;91(3):359-65

7. Penisten DK. Optometric education and optometry in Africa. J Am Optom Assoc. 1993;64(10):726-9.

8. International Agency for the Prevention of Blindness Africa. Situation analysis of optometry in Africa. 2016. Retrieved from: https://www.iapb.org/wp-content/ uploads/Situation-Analysis-of-Optometry-in-Africa_ June-2016.pdf.

9. International Agency for the Prevention of Blindness. Addressing the eye health workforce crisis in SubSaharan Africa: business as usual is not an option. IAPB Policy Paper. 2014. Retrieved from: https://www.iapb. org/wp-content/uploads/Addressing-the-Eye-HealthWorkforce-Crisis-in-Sub-Saharan-Africa.pdf

10. Thylefors B. A global initiative for the elimination of avoidable blindness. Community Eye Health. 1998;11(25):1-3.

11. Brien Holden Vision Institute. Global optometry development. Retrieved from: https://bhvi.org/publichealth/optometry-development.html

12. Carlson AS. Optometry in Ethiopia. S Afr Optom. 2008;67(1):42-44
13. Gyawali R, Bhayal BK. Practice scope and job confidence of two-year trained optometry technicians in Eritrea. BMC Med Educ. 2019;19(1):303.

14. International Agency for the Prevention of Blindness. Malawi optometry association holds inaugural meeting. 2016. Retrieved from https://www.iapb.org/news/ malawi-optometry-association-holds-inauguralmeeting/

15. Chan FV, Loughman J, Moodley VR, Bilotto L, Naidoo K. Student educational background, perceptions and expectations toward optometry: an emerging eye health profession in Mozambique. Optometric Education. 2015;40(2):104-109

16. Kell M. Optometry in Uganda: building blocks of a new profession. Mivision. 2018. Retrieved from: https:// www.mivision.com.au/2018/08/optometry-in-ugandabuilding-blocks-of-a-new-profession/

17. International Agency for the Prevention of Blindness. Uganda's first batch of optometrists. 2019. Retrieved from: https://www.iapb.org/news/ugandas-first-batchof-optometrists/

18. University of Hargeisa College of Medicine and Health Science academic programs. Retrieved from http:// www.uoh-edu.net/college-of-medicine-and-healthscience/

19. Morny KF. Optometry in Ghana. (unpublished manuscript)

20. Ovenseri-Ogbomo GO, Kio FE, Morny EK, Amedo AO, Oriowoe OM. Two decades of optometric education in Ghana: update and recent developments. S Afr Optom. 2011; 70(3):136-141

21. Ogbuehi PO. The development of optometric training in Nigeria. S Afr Optom.1993;52:54-55.

22. Oduntan AO. Thirty years of optometric education at Turfloop: a historical and educational overview. S Afr Optom. 2006;65:34-40

23. Mashige KP. Optometric education at Westville: past, present and future. S Afr Optom. 2010;69(1):14-20

24. Association of Schools and Colleges of Optometry. Residency Program Funding and Promotion Survey Report. 2019. Retrieved from https://optometriceducation.org/wp-content/ uploads/2019/12/ASCO-Residency-Funding-PromotionReport-2018-19.pdf

25. The African Council of Optometry. Guidelines for the accreditation of Low Vision training. 2019. Retrieved from: https://998ff8a7-a3414a7c-b486-31a2c9d5b314.filesusr.com/ ugd/7f9024_663b856e158e49df8040568bf0183319.pdf 